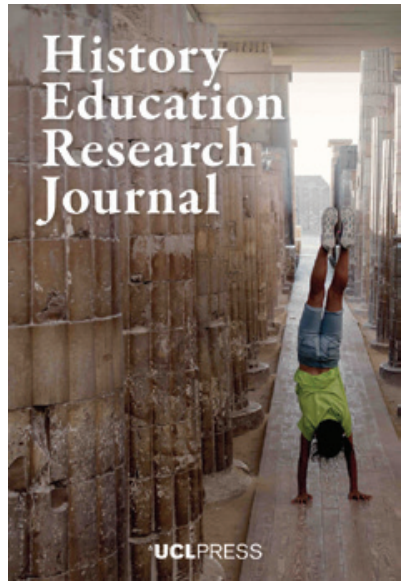

${ }^{\Perp}$ UCLPRESS

HISTORY EDUCATION RESEARCH JOURNAL

ISSN 2631-9713 (Online)

Journal homepage:

https://www.uclpress.co.uk/pages/history-educationresearch-journal

\title{
Perspective as a threshold concept for learning history
}

Javier Paricio iD

\section{How to cite this article}

Paricio, J. (2021) 'Perspective as a threshold concept for learning history'. History Education Research Journal, 18 (1), 109-25. https://doi.org/10.14324/HERJ.18.1.07

Submission date: 23 July 2020

Acceptance date: 17 October 2020

Publication date: 20 April 2021

\section{Peer review}

This article has been peer-reviewed through the journal's standard double-blind peer review, where both the reviewers and authors are anonymized during review.

\section{Copyright}

(C) 2021 Paricio. This is an open-access article distributed under the terms of the Creative Commons Attribution Licence (CC BY) 4.0 https://creativecommons.org/licenses/by/4.0/, which permits unrestricted use, distribution and reproduction in any medium, provided the original author and source are credited.

\section{Open access}

The History Education Research Journal is a peer-reviewed open-access journal. 


\title{
Perspective as a threshold concept for learning history
}

\author{
Javier Paricio* - University of Zaragoza, Spain
}

\begin{abstract}
The epistemological concept of perspective meets all the conditions set by Meyer and Land $(2003,2006)$ to be considered a threshold concept for history learning. Following this initial hypothesis, this paper analyses the concept and the ways in which it constitutes a threshold: grasping perspective not only transforms one's understanding of history, but it is also necessary for many aspects of historical thinking. Yet grappling with perspective is no easy feat, since understanding it requires the learner to confront other deeply rooted concepts and beliefs. Accordingly, the article explains how naive realism and the engrained epistemological tradition embodied in the expression 'facts first' make it difficult to understand history through perspective. Finally, a four-part model outlining different ways of understanding perspective is proposed, thus providing a framework within which we can think about what it means to cross the threshold from naive realism to a perspectivist vision of history.
\end{abstract}

Keywords: threshold concepts, historical thinking, perspectives, multi-perspectivity, historical interpretations

\section{Introduction}

The CHATA project (Concepts of History and Teaching Approaches: 7 to 14) (Lee, 1998; Lee and Ashby, 2000; Lee and Shemilt, 2004) drew attention to the great burden that naive epistemological beliefs pose for the development of students' historical thinking. An inadequate understanding of the nature of history makes it extremely difficult for students to carry out any sort of sophisticated historical interpretation. While the literature on history teaching has often identified the problem, scholars have not frequently delved into the question about the specific nature of students' difficulty in thinking historically, which, I argue, is a prerequisite for considering how to confront the issue in the classroom. This article seeks to elucidate the problem, starting by situating it within the broader framework of three major lines of research: the epistemology of science and history, research on the impact of personal epistemological beliefs on learning, and more recent research on so-called threshold concepts. By situating the issue within these three lines of research, the problem is framed in a fuller, clearer and more precise way, leading to a better understanding of its origins and consequences, as well as the persistent difficulty in overcoming it.

Bringing the findings of these different lines of research into dialogue will allow us to achieve the following: (1) to better define the problem in terms of the need to cross a conceptual threshold between two distinct epistemological positions (naive realism and epistemological perspectivism); (2) to clarify the nature of naive realism and the epistemological concept of perspective; and (3) to explore the complexity of 
crossing this threshold through a four-part model that outlines different conceptions of the epistemological notion of perspective in history.

\section{The starting point: The gap between the epistemological notions of naive realism and perspective as a threshold}

The term 'perspective' is ubiquitous in history. It is used in connection with the metaconcept of empathy or historical perspective taking. We also speak of historical perspective when we trace the processes of change and continuity that have given rise to a particular situation. Finally, we often use the word in relation to historical accounts when referring to the multi-perspectival nature of history. Yet, are we speaking about the same perspective in each of these three instances? We think that, although situated in different problems and contexts, the term 'perspective' does indeed refer to a single underlying concept of an epistemological nature. Nietzsche (1989: 119) drew our attention to the concept when he denied the possibility of having any objective knowledge about the world: 'there is only a perspective seeing, only a perspective "knowing"'. Thomas Kuhn (1962) brought this same concept to bear specifically on academia with his theory of scientific paradigms. Human beings cannot strip themselves of what they are, that is, their thoughts and feelings, and consequently any discourse must necessarily draw on the subject's very humanity, which says as much about the speaker's way of being and thinking as it does about the object of the discourse itself.

The very heart of this concept of perspective can be summarized thus: from its very root (in its language, syntactic order, structure and so on), any representation incorporates an order and a meaning that is not in the represented world, but is projected by the human being who creates it from his/her own perspective. This means that history does not uncover an already existing reality of the past world, but rather constructs an intelligible, ordered and meaningful reality by representing the world of the past from a given perspective. Rorty (1989: 5) has expressed this notion succinctly: 'The world does not speak. Only we do.' The world does not have a particular form: we human beings give it form when we try to understand it with our concepts, stories and theories. 'Truth cannot be out there - it cannot exist independently of the human mind - ... The world is out there, but the descriptions of the world are not' (Rorty, 1989: 5).

Ourstarting point is the need to situate ourselves in a perspectivistepistemological conception in order to reason historically. But this idea that any historical account originates and takes shape in a particular perspective (historiographical, ideological, contextual, affective and so on) is opposed to the simplistic belief of our students that history emerges in a non-problematic way: all we need to do is simply find the facts out there, which should be able to offer up a mirror of the past. Epistemologists have often identified such thinking as a form of naive realism. In this sense, this article deals with the problem of how we can move from a naive realist view of history to a perspectivist epistemology.

By proposing that perspective should be understood as a threshold concept, we argue that there is a problematic and transcendental stumbling block for the study of history, and that the notion of threshold concepts allows us to think about perspective in a new and fruitful way, by drawing on an important body of research:

A threshold concept can be considered as akin to a portal, opening up

a new and previously inaccessible way of thinking about something.

It represents a transformed way of understanding, or interpreting, or 
viewing something without which the learner cannot progress. (Meyer and Land, 2006: 3)

As befits a threshold concept, the idea of perspective involves crossing a boundary between two qualitatively different ways of thinking. It is a cognitive portal to a new way of thinking in a domain. We can define this threshold as the passage from naive realism (the belief in an objective and accessible past reality as the starting point), to a vision of perspective as the necessary starting point of any historical undertaking.

Research on threshold concepts starts with an analysis of the difficulties that students have that prevent them from thinking like an expert. This analysis leads to the identification of certain fundamental concepts on which experts' ways of thinking and practising are based, and which can be stumbling blocks for students. These concepts act as a threshold which one must cross to acquire a new way of thinking and, accordingly, they can obstruct 'the journey from novice to mastery within their discipline' (Higgs, 2014: 13). They are authentic bottlenecks, as David Pace (2017; Middendorf and Pace, 2004) called them in an area of research that is very closely related to that of threshold concepts. In many disciplinary fields, dozens and even hundreds of publications have accumulated over the last decade that attempt to identify and characterize these threshold concepts, which quite often are of an epistemological nature (Higgs and Cronin, 2013). In history, I have been unable to find any scholarly publication that proposes what the threshold concepts for the discipline are.

To begin, it is worth asking whether these threshold concepts are not the same as second-order concepts proposed for historical thinking. In other words, is this just a matter of terminology? If we take the meta-concepts found in three authoritative models - Lee (2005), Lévesque (2011) and Seixas and Morton (2013) - we can see that in many cases this is clearly not the case, although it could be in others. What characterizes a threshold concept is that a simplistic, naive or partial understanding of that concept prevents expert reasoning in a given field; the development of a more complex and deeper idea of the concept opens the door to more advanced ways of reasoning. In this sense, a naive conception of causality - understood in terms of simple intention, for example (Carretero et al., 1997) - obstructs proper causal reasoning. It is necessary to develop a more multidimensional, complex, abstract and social conception of causality in history in order to reason like a historian. Historical causality is clearly a good candidate for being a threshold concept in history.

The term empathy, or historical perspective taking, for its part, refers more to a process than a concept. The key that opens/closes the way to expert reasoning in this field is the epistemological concept of perspective. Presentism is but a form of naive realism, insofar as it consists in the improper universalization of our own perspective ('the world is as I conceive it'). To move towards expert reasoning through historical perspective, one must begin with a deep appreciation of the fact that all human discourse and action arise from a certain interpretation of things, are built from a particular perspective, and progressively develop an awareness of the complexity of the various dimensions that compromise the perspective from which all individuals interpret the world (for example, ideologies, beliefs, theories, representations, emotions and contexts).

What is most intriguing about the epistemological threshold concept of perspective is, in my view, how it also lies behind the expert reasoning related to other meta-concepts, in particular historical account (Lee model), primary sources (Lee/Lévesque/Seixas and Morton models) and historical significance (Lévesque/ Seixas and Morton models). It is the development of the epistemological concept of perspective that allows us to understand the diversity of historical accounts and the 
very nature of the process of interpreting the past from the sources. In the case of historical significance, establishing criteria for selecting information and determining its relevance cannot be done without this notion of perspective. In short, the threshold is a glass wall that prevents students from understanding the nature of historical stories and arguments, as well as much of the processes that lead to their construction.

'Perspective' meets all the conditions to be considered as a threshold concept, as formulated by Meyer and Land (2003, 2005, 2006), and within the framework of more general research on understanding and deep learning (Perkins, 1998, 2009; Marton et al., 2005; Entwistle, 2009):

- thinking history through a perspectivist conception is challenging for students because of the strong roots of their naive conceptions

- not having this concept bars access to historians' ways of thinking and practising their craft

- crossing the threshold is transformative for students because it changes their way of interpreting history as well as the wider world around them.

As is the case with any threshold concept, it is common for the cause of 'blockage' to go unnoticed, since the underlying difficulty is based on the inadequacy of a previous naive and implicit understanding. Naive realism (the belief that one can discover and represent the (definitive) truth of things, things as they are) is a largely implicit view of the world. Above all, however, this theory warns us of the transcendental importance of designing the curriculum around these threshold concepts, so that students can gradually move towards the way of thinking and practising used by experts in a given field. As Shinners-Kennedy (2016: 253) points out, 'the acquisition of a threshold concept causes knowledge integration and transforms the learner's view of their discipline and possibly even their world'.

\section{The problem of naive realism}

The findings of the CHATA project (Lee, 1998; Lee and Ashby, 2000; Lee and Shemilt, 2004) have shown how young students tend to think that good history should provide an accurate mirror of the past. When this is not the case, students resort to a standard list of explanations: historians made mistakes, there were errors or biases in the sources or process of transmission or, finally, that historians let their opinions get in the way and distort the facts. The most advanced students recognize that the overwhelming vastness of the past obliges historians to make choices, a fact that can explain why two different accounts of the same past could exist. Very few, however, manage to glimpse that each historical account emanates from the particular perspective from within which each historian undertakes his/her project. For students, history is often a simple 'picture of the past', and it is assumed that 'there should be one best picture', as Shemilt puts it (2000: 85). 'If a story was told and it was all correct, and copied what actually happened, it could be the only true story', explained Geoff, an 11- or 12-yearold student (in Lee and Shemilt, 2004: 26).

Arthur Chapman (2011a: 97) has more precisely located the origin of the problem in the 'tacit assumptions, based on everyday epistemologies that are likely to impede the development of their understanding of historical interpretation'. Naive personal epistemologies are frameworks for knowing and understanding. Any task assigned to a student is filtered through these general and discipline-specific epistemological beliefs, deeply conditioning the cognitive processes of thinking and reasoning (Hofer and Pintrich, 1997; Schreiber and Shinn, 2003). VanSledright (2002: 50) has highlighted 
a revealing classroom experience that well illustrates the decisive and persistent influence that naive epistemological beliefs can have on reasoning and learning: when 'the inner interpretive machinery of doing history' was revealed to them, his students abruptly moved from blind trust in historical sources and accounts to outright distrust 'I was struck by the frequency with which several students concluded that they could no longer trust most of the evidence they encountered'.

Although it may seem surprising, this abrupt leap from belief in absolute truth to belief in widespread lying is not all that surprising, insofar as both positions are typical manifestations of naive realism. Both emerge from the uncritical assumption that the world is as one sees it, and that to tell the truth is simply a matter of not lying: the world, identified with an individual's own view, is transparent and immediate. From a naive-realist view of the world, one can only tell the truth or lie, and be right or wrong. VanSledright (2002: 51) calls this 'referential illusion', and attributes the apparent change to the 'resilience of their epistemological positions'. For these students, we could access the 'real truth' 'as long as we could get to the "right" evidence that conveyed it', and, wherever we find different stories, it is because someone is lying: 'Despite these repeated efforts, several students continued to prefer the idea that much of the evidence simply couldn't be trusted because people regularly and intentionally distorted the truth' (VanSledright, 2002: 51).

Above all, VanSledright's (2002) experience reveals the difficulty of leaving behind naive realism. Students 'escape' the author's efforts to demonstrate the interpretative nature of historical accounts by jumping to the second term in the naive-realist binary: right/wrong, truth/falsehood. There is nowhere else to go with this epistemological paradigm. This problematic aspect of the concept is the first reason why we identify it as a threshold concept: it is a barrier, an invisible obstacle made up of implicit ideas.

The work of William Perry (1970), often considered the inaugural moment of research on the impact of personal epistemologies on learning, already identified 'dualism' as the generalized epistemological default conception of students: knowledge is simple and closed, and it consists of absolute truths (right/wrong) that can be revealed by an authoritative expert. In Schommer's (1990) well-known multidimensional model, the initial stage also entails the belief in simple, true, fixed and authoritative knowledge, which corresponds nicely with the observations outlined above from the history classroom. But the origin of this dualism must be sought in the philosophical concept of naive realism. Following in the wake of Kant, in chapter 1 of The Phenomenology of Spirit, Hegel (1807) argues against what he calls 'sense-certainty', a naive realism consisting in the belief that the world, as it is, can be known intuitively and immediately without being mediated through concepts (Westphal, 2000). For someone functioning within this naive realism, if the world can be known intuitively and described as it is, knowledge is not problematic; rather, it is simple and fixed. What we say can only be true or false, right or wrong. When applied to history, then, historical endeavour boils down to telling the truth about the past, as it was.

The negative influence of this kind of naive epistemological belief on learning has been extensively documented (Schommer, 1990, 1994; Hofer, 2001; SchommerAikins, 2004). In general, more sophisticated and complex epistemological beliefs have been associated with better academic achievement, particularly in loosely structured tasks that require reflective judgement (Schommer, 1990; Tolhurts, 2007; Lodewyk, 2007), deeper levels of understanding (Schommer, 1990), and higher-order thinking processes (Bendixen and Hartley, 2003; Dean and Kuhn, 2003; Schommer-Aikins and Hutter, 2002; Schommer-Aikins and Easter, 2006). 
Particularly relevant for the present issue are studies that have shown how more advanced epistemological beliefs are related to an increased capacity to deal with competing claims and evaluate alternative points of view (Kardash and Scholes, 1996; Rukavina and Daneman, 1996; Strømsø and Ivar, 2009; Ferguson et al., 2013; Trevors et al., 2017). For example, when studying climate change from multiple conflicting sources, students with more complex epistemological beliefs not only achieved better results, but also reported higher levels of enjoyment and curiosity, as well as lower levels of anxiety and confusion (Bråten et al., 2008; Bråten et al., 2011; Muis et al., 2015):

The more the participants believed in complex and tentative knowledge, the more likely they were to take on multiple perspectives, be willing to modify their thinking, withhold ultimate decisions until all information was available, and acknowledge the complex, tentative nature of everyday issues. (Schommer-Aikins and Hutter, 2002: 5)

These results support our initial hypothesis that naive realism lies behind a significant part of students' problems with reasoning historically, to the extent that the ability to work critically with divergent historical texts, with diverse and often conflicting sources or contrasting perspectives of historical figures, is a requirement of historical thinking. Consequently, naive realism would be behind not only an inadequate conception of the nature of history, as the CHATA project taught us, but also behind many of the problems observed in working with sources (Barton, 1997, 2005; McAleavy, 1998; Ashby, 2004; Pickles, 2010), presentism in historical perspective taking (Ashby and Lee, 1987; Lee and Ashby, 2001; Kohlmeier, 2006; Endacott, 2014) and the difficulties of understanding the selection of historical significance criteria (Barton and Levstik, 1998; Lévesque, 2005; Cercadillo, 2006). The cost of not crossing the threshold between naive realism and awareness of perspective is very high.

\section{Naive realism: Not only a personal belief, but a whole cultural and historical tradition}

Naive realism has a twofold point of departure: (1) the world has a certain form; and (2) human beings are capable of knowing that form. Of course, naive realism is not usually so naive as to think that there are no subjective or interested opinions, and no ignorance or deception. This is among the first things that students think when faced with multiple sources or stories (Lee, 2004; Lee and Shemilt, 2004; Chapman, 2011b, 2011c). What characterizes naive realism is its confidence that reality is a certain and single way, that there is a reality (and the rest can be chalked up to distortion, bias or ignorance) and that, naturally, the world can be perceived as it really is.

In history, as in journalism and other disciplines, naive realism is condensed into the expression 'the facts first'. The editor of The Guardian, C.P. Scott, expressed it in 1921 in a famous editorial that has remained a declaration of independence of the journalistic endeavour: 'Comment is free, but facts are sacred.' Thus, the distinction between information and opinion remains a defining aspect of journalism. Likewise, facts were hailed as the cornerstone of the historical discipline at its very inception in the nineteenth century. This view is commonly attributed to Leopold von Ranke (2011), and his famous call in 1824 to present the past 'wie es eigentlich gewesen', usually translated as 'what actually happened', 'as it really was' or 'simply tell how it was' (Boldt, 2019). 'The strict presentation of facts, however contingent and unattractive it may be, is undoubtedly the supreme law' (Ranke, 2011: 57). Facts were baptized as the 
scientific part of the discipline, in contrast to interpretations, which were seen as the controversial, suspicious or risky aspect of the historical craft.

The idea that it is possible to write a true history, a faithful mirror of the past, has a long tradition that can be traced back to antiquity. Distinguishing between rhetoric and history in first-century Rome, Cicero calls attention to the veritas of historical writing: 'Who does not know history's first law to be that an author must not dare to tell anything but the truth? And the second that he must make bold to tell the whole truth?' (Breisach, 2007: 57). Lucian, a Greek writer of the second century CE, proposed that historians should 'bring a mind like a mirror, clear, gleaming-bright, accurately centred, displaying the shape of things just as he receives them, free from distortion, false colouring or mis-representation' to leave nothing less than 'a true account of what happened' (Southgate, 2001: 14). As Southgate (2001: 13) puts it: 'Underlying such a view is a belief that there is a past reality or truth, waiting to be discovered and described. The historian just has to clear away the darkness and confusion.'

This was also the dream of Lord Acton and his Cambridge Modern History at the end of the nineteenth century: to establish an objective and impartial history, outside human subjectivity, with a 'clean writing' that simply and indisputably reflects the facts as they have been established by the specialists. There was absolutely no place in Acton's plan for the individual historian's perspective, only the reality of the facts. But what is really enlightening about Acton's letters is that in no way does he consider this demand to be in contradiction with a second demand that authors never relax the standards of 'rectitude' in the exercise of ethical judgement on historical characters and events, exhorting that 'no man and no cause [be allowed] to escape the undying penalty which history has the power to inflict on wrong ... The inflexible integrity of the moral code is, to me, the secret of the authority, the dignity, the utility of history' (Altholz, 1996: 731). Immovable and eternal values are the bedrock on which a definitive history is to be written; naive realism here reveals its dangerous proximity to dogmatism.

The distinction between the 'hard core of facts' and the 'surrounding pulp of disputable interpretation', to use Sir George Clark's words (Carr, 1990: 9), represents a powerful tradition with deep roots in all domains, including that of the teaching of history. The slogan 'the facts first' (the 'objective basis') remains today a commonplace in many curricula, turning history into a sort of encyclopedia where fragmented data and facts are accumulated in an extremely extensive, debatably impressive, but almost certainly useless, way.

Naive realism is not only naive, but also a strong epistemological position that has formed the centrepiece of a long curricular tradition within history education. Furthermore, the confidence that things of the world can be described as they truly are can be traced back to Pythagorean or Platonic ontological realism. Ultimately, crossing the threshold of perspective means renouncing the old myth that the universe has an order and harmony that we can discover. It is that divine order that so well represents that medieval image of God as the architect of the world, using his compass to place everything in its proper place. This would be the 'true world' behind the world of appearances - order and meaning behind the apparent chaos of experience.

As some authors have pointed out, learning to think about history is not something that comes naturally (Chapman, 2011 b; Lee, 2005; Wineburg, 2001). On the contrary, it entails a remarkable effort and difficulty that stems, in my opinion, from the problematic and counter-intuitive nature of the concept of perspective, starting with the renunciation of that reassuring distinction between facts and interpretations that accounts for the diversity of stories and theories without renouncing realism. It is then that we feel restless, and perceive the enormous amount of energy required to cross 
the threshold and reject naive realism and the weighty historical and cultural tradition that it brings with it.

\section{The epistemological concept of perspective}

As demonstrated by a long history of philosophical and methodological reflection, perspective is certainly a complex and controversial idea, which has given rise to a series of debates that can be summarized in two questions.

First, can science escape from the particular perspective of those who make it and represent the world as it really is, regardless of the necessarily individual and contextualized positions of human beings? Many currents of scientific realism answer this question affirmatively, maintaining that it is possible to arrive at - or at least get very close to - the truth of things, the world as it really is, and even history as it really was. According to this line of argumentation, science, through an ongoing process of refinement and increasing methodological rigour, can manage to overcome subjectivity and provide an objective representation of the world. The idea of perspective denies this possibility: as human beings, we always look from a certain, historically and contextually conditioned position. Our context, language, conceptions, beliefs, knowledge, interests, experiences and emotions determine the way in which we interrogate the world and the assumptions that aid us in so doing. While our perspective may change or evolve, we can never stop interpreting things from a certain perspective. It is not possible to speak of an objective truth that can be observed from beyond the point of view of human beings, because that point of view does not exist or is unattainable.

Second, if we admit that we cannot attain the truth of things because we cannot avoid thinking from a certain perspective, does this mean that there is no longer any form of truth? Many perspectivist theorists resist this idea, and instead argue that, even if no single, absolute truth can be attained, historical or scientific discourse can attain some degree of truth when it is consistent with empirical observations and available evidence. In contrast to this realistic perspectivism, we find anti-realism, which claims that any observation or experiment is always conceived according to a certain perspective. Does this anti-realist perspectivism equate to absolute relativism? To a certain extent, the answer is yes, although it is still possible to defend the greater validity and credibility of certain discourses by virtue of their internal or external coherence, or the consensus they elicit in the scholarly community.

In the history teaching community, it has been usual to defend the rigour of the discipline, trying to show that multiplicity of perspectives does not mean absolute relativism. It is not difficult to detect here a certain defensive posture, as if the value of the discipline were at stake when we state that it does not represent an objective truth. To think that the starting point of any history is a perspective, and not the supposed reality of things, may be difficult for some to accept, but it does not undermine the discipline. The basic mandate that every academic discourse be demonstrably consistent with the available evidence remains valid in the ever-elusive terrain of history and its use of sources. Bas van Fraassen (1980: 19) called empirical adequacy the requirement that every theory 'fit the observable phenomena', which, in our case, would be the evidence and data culled from the sources and remains of the past.

A perspectivist approach to history naturally emanates from the simple acknowledgement of the multiple perspectives that intersect in historiography. This view, however, is not so widely accepted in other disciplines. It is therefore necessary to ask whether there is anything unique about history. 
Dilthey's (1883) distinction between explanation [Erklären] (associated with the experimental sciences) and understanding [Verstehen] (associated with the humanities and social sciences) has been a keystone for decades in defending the particular status of history as a discipline. However, scholarly discussions, including Nietzsche's perspectivism (1968), Thomas Kuhn's notion of paradigms (1962), Richard Rorty's philosophy $(1989,2003)$, and the perspectival realism advocated by Michela Massimi (2018a, 2018b; Massimi and McCoy, 2020; Crețu and Massimi, 2020), argue that any scientific theory, even in fields as paradigmatically experimental as physics, must be understood within the framework of a perspective that is culturally and historically determined.

While I do share the arguments about the unavoidable perspectival nature of any scientific and human discourse, I nevertheless believe that it is necessary to engage with Dilthey's influential principle of the special status of history (and of much of the humanities and social sciences). In stark contrast to nature, all human acts and creations are endowed with meaning from their very origin. The semiotic nature of the object of study is what constitutes this difference. The historian thus combines a double perspective: his/her own perspective as a historian (with the particular meaning created by his/her interpretation), and the perspective of the people of the past (with the interpretation and meaning associated with their actions and decisions). We interpret, on the one hand, the acts and works of the past as if they were a text whose original meaning must be decoded and explained, and, on the other hand, we historically interpret the whole from our own present perspective.

The articulation, which is not without tension, between these two perspectives is what specifically conditions historical reasoning. On the one hand, the historian enters into the 'foreign' perspective of men and women in the past in order to glimpse different forms of believing, thinking, experiencing and even feeling (Endacott and Brooks, 2013) - Sam Wineburg (2001) has beautifully described the potential and richness of this encounter with the strange. On the other hand, from the historian's own perspective, it is necessary to maintain that distance discussed by Gadamer (1960) or Ranke (2011) as a distinctive mark of the discipline. Put slightly differently, the historian must maintain the coherence and rules of the game of his/her own perspective.

Both perspectives converge at one point: they force us to become aware of - to denaturalize - our own perspective. The concept of perspective emphasizes the subject and, in so doing, makes us aware of our own subjectivity as one among many other subjectivities. The claim of an objective science beyond any subjectivity (hence, beyond the human) does not make science more valuable. Quite the contrary, from this point of view, the necessarily perspectival nature of science and all scholarly undertakings, including history, is the axis on which its value is articulated. The idea of perspective emphasizes that, through investigation and research, we try to make the world intelligible to us (in a way adapted to our ideas, beliefs, experiences, problems and needs). Putting scholarly practice in perspective requires recognizing the subjects who want to understand their world in order to solve their problems, or simply to answer their specific questions. History in perspective, with its multiple perspectives, speaks to us of the diversity of human experience in the world, of constant change, and of the contingent and extraordinarily diverse nature of the ideas with which we intend to make our own sense of the world. The conventions and rules upon which we seek to base objective knowledge will always be ours; we use them, here and now, to establish a base for shared deliberation. The fact that they are not the definitive rules does not detract from their value; on the contrary, it is what makes knowledge suitable for us and our problems now. The fact that our history is not the history does not make 
it any less valuable, since it is a conduit that allows us to generate our own meaning and value.

\section{The difficulty of crossing the threshold}

Every threshold is a point of transition between two spaces. A learning threshold is characterized by the difference between the place of departure and arrival, as well as the obstacles that complicate passage. It does not consist simply in the exploration of the concept itself (place of arrival), but in the analysis of the particular cognitive or emotional 'jump' required to get there from previous ideas and conceptions. As Ray Land (2015: 20) points out, this transit entails 'rupture and uncertainty' and 'sense of loss', precisely because it requires 'letting go of a prior familiar view' - the leap from a familiar and relatively safe territory to an uncomfortable, strange and potentially threatening place.

In our case, what is that comfortable and familiar place that we leave behind? Naive realism, the intimate conviction that we see the world as it is. The idea that things may not be as they seem is, indeed, uncomfortable and unsettling. Without any thought, we assume that our representation is not constructed from our particular perspective, but rather that it emanates from the very nature of things reflecting themselves on our minds. It seems so obvious that things are as I see them! It takes a great deal of energy to realize that it might not be so.

\section{Crossing the threshold: Four versions of understanding perspective in history}

It is not simply the difficulty of leaving behind naive realism that makes crossing the threshold problematic: the epistemological concept of perspective is itself extraordinarily complex. Diverging explanations for the multiplicity of historical accounts concerning the same past attest to the fact that we are not always talking about the same thing when we refer to the multiple perspectives in history. Through an exercise of conceptual analysis (Jackson, 1998; Laurence and Margolis, 2003; Beaney, 2014), we can distinguish between four different conceptions of increasing complexity and radicality. The following discussion is meant to support the general argument of this paper in order to better visualize what it means to cross the threshold of naive realism. Importantly, we are not putting forth a model of progression like those that have already been proposed for the various meta-concepts of historical thinking, which are necessarily of an empirical nature. What follows, then, should not be understood as stages or levels, but rather ways of understanding the concept of perspective, ordered in terms of increasing complexity and difficulty for students. Table 1 shows the different steps in the increasingly sophisticated understanding of how perspective understands history. Each step presupposes the previous one, although it metamorphosizes previous understandings into new notions.

(1) Perspective as selection. The existence of multiple acceptable histories can be justified, in the first instance, by claiming that the past is so vast that no single history can ever encapsulate all its facets and details. The particular perspective of the historian is thus concretized through his/her selection criterion, which directs and restricts the historical discourse to specific aspects of the past. History would in no case represent the facts, as Lord Acton wanted, but only a part - really just a tiny fraction - of the full body of those facts. This notion of perspective is relatively easy to understand, but it 


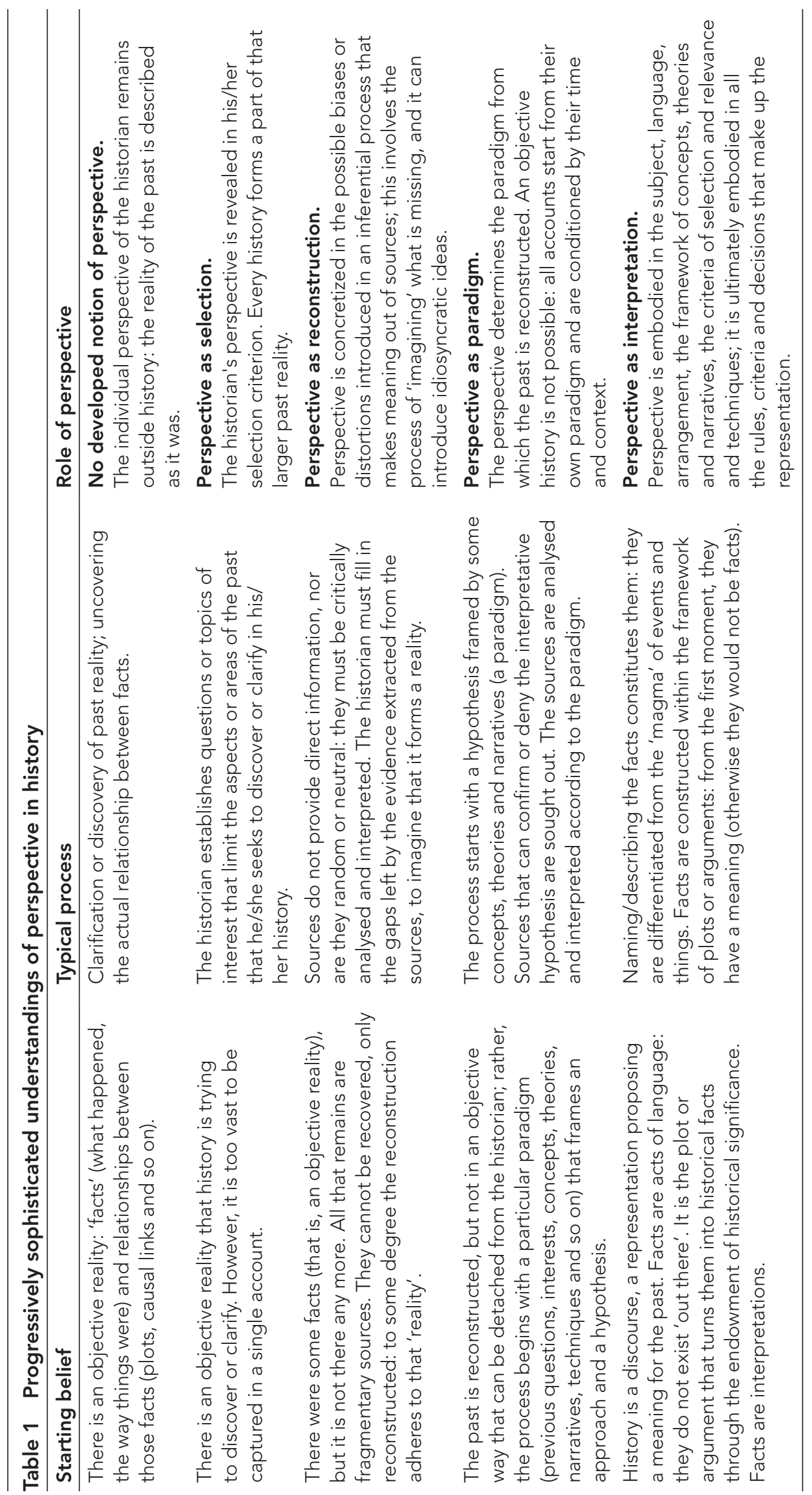


is also limited. Studies derived from the CHATA project have shown how this notion of perspective can be detected among students aged 13-14 (Lee, 1998; Lee and Ashby, 2000; Lee and Shemilt, 2004).

Recognition of varying selection principles is a valuable first step, but in and of itself it does not take us much beyond naive realism. At no time is the objectivity of facts questioned, or the opposition between facts and interpretations challenged.

(2) Perspective as reconstruction. The object of historical study, unlike other disciplines, no longer exists. It has vanished. The past is fundamentally unobservable (Turner, 2004). Nothing we can say about it can ever be verified (Lowenthal, 2015). The historian's point of departure can in no way be any objective fact, but rather the fragmentary traces and scraps that have survived the passage of time. The facts are not there waiting to be picked out and used: they do not exist prior to the beginning of the historical endeavour (McKeon, 1972). Nor do these sources dictate the facts. The historian must intervene in a double sense. On the one hand, he/she contextualizes and critically analyses sources in order to draw inferences from them, and, on the other hand, he/she fills in the gaps left by these inferences from the sources, a process that requires imagining the rest so as to craft a credible and coherent past world. In no case can there be objective facts: they are a construction of the historian, fruit of his/her analytical work, inference and controlled imaginative reconstruction from the sources. Each historian thus models history according to his/her perspective, understood here as his/her particular way of carrying out this work of analysis, inference and reconstruction.

The distance from the illusion of naive realism widens. There are no longer hidden objective facts out there waiting to be discovered.

(3) Perspective as paradigm. Any historical narrative is built from a predetermined conceptual, theoretical and narrative framework. A more or less open question and a flexible hypothesis are framed within a certain paradigm that guides the entire process. Paradigm is understood here not only in the strict sense of Kuhn's (1962) scientific paradigm (a 'disciplinary matrix' of shared purposes, concepts, hypotheses, techniques or criteria), but also as a personal intellectual framework, made up of beliefs, experiences, interests, narratives, values, ideology, contextual conditions or feelings. That is why in each period, each historian can make the evidence speak in a particular way or can interrogate different sets of evidence. So, with each new history, new historical facts appear, while others disappear, and many change their appearance. The perspective of each historian, understood here as a paradigm, determines the question and hypotheses on which history is based; the paradigm models the facts that will outline that history, and gives way to the plots and arguments that will weave those facts together. Each history is different because it is sprung from a different paradigm.

Does this mean that we construct the facts, the supposed reality of the past, to our measure? It does indeed, so long as we do not understand it as if cut out of whole cloth, as a novelist might. Each proposed history must be consistent with the available remains of the past, must be justified in the rigorous treatment and dispassionate assessment of those sources, and is subject to the scrutiny and deliberation of the community of experts. There is a great deal of distance between this process and the writing of a novel.

Perspective as a paradigm is far removed from naive realism. It places us in a squarely perspectivist vision of history. This conception of perspective transforms historical reasoning in many of its dimensions, and it allows for a fuller understanding of the discipline's meta-concepts. 
(4) Perspective as interpretation. History is discourse, and perspective is the order and meaning produced by that discourse. It is not what is in the mind of the historian. It is not a filter of previous ideas through which we see the past. Here, the prevalent metaphor of perspective as 'point of view' becomes misleading. Perspective is the form that models discourse, and, consequently, it is inseparable from it. It is created in the historian's effort to construct a meaningful discourse about the world of the past. What is emphasized here is the (sharp, but problematic) separation between language and the world. History is a representation, not of the world of the past, but of the historian's grappling with the traces of that past world and what others have said about it. Through the reading of that representation (particularly if it takes a narrative form), we find ourselves before the past as it could have been, a world with apparent coherence. But this is only a textual effect. The coherence and the meaning that we appreciate in that representation is perspective.

Facts are not only constructed within the framework of a paradigm; they are created and shaped by and for the history to be told. From the very moment of their formulation, they are inserted into a plot or argument, they form part of an order, and are, therefore, endowed with a certain meaning. A historical fact is so because it is part of a historical plot or argument that lends it significance and, to the same extent, constitutes it as a historical fact.

There was a world in the past and an infinite number of things happened there every minute: an unruly magma of events, beings and objects. But beyond that mere existence, there is no truth with which historical discourse can correspond. The past has no order, no meaning, no truth; it is human discourse that has those characteristics. What we see in every history is an intelligible reality, endowed with a certain order and sense; we see different and significant facts linked together by plots and arguments. What we see, in short, is a discourse. The meaning is not out there. We make representations to interpret and understand the world, not to show it as it is.

And this final conception, required to fully cross the threshold, is particularly difficult to take.

\section{Conclusion}

Experiences in the history classroom since the CHATA project have shown us that students conceive of history as a faithful representation of the past, and that this naive epistemological belief seriously undermines their ability to think historically. Decades of research in many other disciplines also support this conclusion and suggest that a mature conception of knowledge is necessary for being able to reason with multiple conflicting texts, something that is absolutely essential for historical thinking.

Basing the discussion within the realm of epistemology, we have characterized students' initial beliefs in terms of naive realism. The analysis reveals that naive realism is not only a default belief with deep roots, but also a strong cultural tradition and epistemological constant in history education. Leaving behind naive realism is, as has been observed in classroom experiences, a problematic learning process. But once we have left this behind, where are we exactly? My contention is that the destination is a perspectivist conception of history. This article has tried to elucidate the concept of perspective, first in general epistemological terms, and then through a more specific analysis of what 'perspective' means in history. The four conceptions of perspective that are proposed (selection, reconstruction, paradigm and interpretation) try to demonstrate the complexity of the concept, with different levels of difficulty and radicality, but, importantly, all of them move us away from naive realism. 
Based on the growing theory of threshold concepts, which has provided promising results in other disciplines, I propose that the epistemological concept of perspective is a threshold for the learning of history. The transition from naive realism to a perspectivist conception constitutes a critical boundary that, once crossed, can grant students access to more expert forms of historical reasoning, and hence it is a prerequisite for at least four of the second-order concepts that have been proposed in different models.

The contribution of this article has been limited to proposing a conceptual framework through which we can rethink and analyse a problem that was detected in the history classroom several decades ago. I believe, however, that it remains so urgent a problem for history education that it is pressing to describe it as precisely as possible, employing the theoretical frameworks offered by two of the most important areas of research in recent decades. I believe - or at least hope - that the conceptual framework proposed here will be useful for interpreting what happens in the classroom, and for conceiving of more suitable learning activities to help students cross a transformational threshold.

\section{Notes on the contributor}

Javier Paricio is a professor of didactics of social sciences in the Faculty of Education, University of Zaragoza, Spain. He is a graduate in art history, with a PhD in education, and he has been Director of the Institute of Education Sciences and Vice-rector for Innovation and Teaching Quality at the University of Zaragoza.

\section{References}

Altholz, J.L. (1996) 'Lord Acton and the plan of the Cambridge Modern History'. The Historical Journal, 39 (3), 723-36. https://www.jstor.org/stable/2639967.

Ashby, R. (2004) 'Developing a concept of historical evidence: Students' ideas about testing singular factual claims'. International Journal of Historical Learning, Teaching and Research, 4 (2), 44-55. https://doi.org/10.18546/HERJ.04.2.06.

Ashby, R. and Lee, P.J. (1987) 'Children's concepts of empathy and understanding in history'. In Portal, C. (ed.), The History Curriculum for Teachers. London: The Falmer Press, 62-88.

Barton, K.C. (1997) '"I just kinda know": Elementary students' ideas about historical evidence'. Theory \& Research in Social Education, 25 (4), 407-30. https://doi.org/10.1080/00933104.199 7.10505821.

Barton, K.C. (2005) 'Primary sources in history: Breaking through the myths'. Phi Delta Kappan, 86 (10), 745-53. https://doi.org/10.1177/003172170508601006.

Barton, K.C. and Levstik, L.S. (1998) ' "It wasn't a good part of history" National identity and students' explanations of historical significance'. Teachers College Record, 99 (3), 478-513.

Beaney, M. (2014) 'Analysis'. In Zalta, E.N. (ed.), Stanford Encyclopedia of Philosophy. https://plato.stanford.edu/entries/analysis/ (accessed 30 December 2020).

Bendixen, L. and Hartley, K. (2003) 'Successful learning with hypermedia: The role of epistemological beliefs and metacognitive awareness'. Journal of Educational Computing Research, 28 (1), 15-30. https://doi.org/10.2190\%2F2Y7C-KRDV-5U01-UJGA.

Boldt, A.D. (2019) Leopold von Ranke: A biography. Abingdon: Routledge.

Bråten, I., Strømsø, H.I. and Samuelstuen, M.S. (2008) 'Are sophisticated students always better? The role of topic-specific personal epistemology in the understanding of multiple expository texts'. Contemporary Educational Psychology, 33 (4), 814-40. https://doi.org/10.1016/j.cedpsych.2008.02.001.

Bråten, I., Britt, M.A., Strømsø, H.I. and Rouet, J.-F. (2011) 'The role of epistemic beliefs in the comprehension of multiple expository texts: Toward an integrated model'. Educational Psychologist, 46 (1), 48-70. https://doi.org/10.1080/00461520.2011.538647.

Breisach, E. (2007) Historiography: Ancient, medieval, and modern. 3rd ed. Chicago: University of Chicago Press. 
Carr, E.H. (1990) What is History? 2nd ed. London: Penguin.

Carretero, M., López-Manjón, A. and Jacott, L. (1997) 'Explaining historical events'. International Journal of Educational Research, 27 (3), 245-53. https://doi.org/10.1016/S0883-0355(97)89732-7.

Cercadillo, L. (2006) '"Maybe they haven't decided yet what is right": English and Spanish perspectives on teaching historical significance'. Teaching History, 125, 6-9.

Chapman, A. (2011a) 'Historical interpretations'. In Davies, I. (ed.), Debates in History Teaching. Oxford: Routledge, 96-108.

Chapman, A. (2011b) 'Understanding historical knowing: Evidence and accounts'. In Perikleous, L. and Shemilt D. (eds), The Future of the Past: Why history education matters. Nicosia: The Association for Historical Dialogue and Research (AHDR), 169-216.

Chapman, A. (2011c) 'Twist and shout? Developing sixth-form students' thinking about historical interpretation'. Teaching History, 142, 24-33.

Crețu, A.-M. and Massimi, M. (eds) (2020) Knowledge from a Human Point of View. Cham: Springer.

Dean, D. and Kuhn, D. (2003) Metacognition and Critical Thinking. New York: Teachers College, Columbia University (ERIC Document Reproduction Service No. ED477930).

Dilthey, W. (1883) Einleitung in die Geisteswissenschaften. Leipzig: Vandenhoeck \& Ruprecht.

Endacott, J.L. (2014) 'Negotiating the process of historical empathy'. Theory \& Research in Social Education, 42 (1), 4-34. https://doi.org/10.1080/00933104.2013.826158.

Endacott, J.L. and Brooks, S. (2013) 'An updated theoretical and practical model for promoting historical empathy'. Social Studies Research \& Practice, 8 (1), 41-58. www.researchgate.net/ publication/270285762_An_Updated_Theoretical_and_Practical_Model_for_Promoting_ Historical_Empathy (accessed 30 December 2020).

Entwistle, N. (2009) Teaching for Understanding at University: Deep approaches and distinctive ways of thinking. Basingstoke: Palgrave Macmillan.

Ferguson, L.E., Bråten, I., Strømsø, H.I. and Anmarkrud, Ø. (2013) 'Epistemic beliefs and comprehension in the context of reading multiple documents: Examining the role of conflict'. International Journal of Educational Research, 62, 100-14. https://doi.org/10.1016/j.ijer.2013.07.001.

Gadamer, H.-G. (1960) Wahrheit und Methode. Tübingen: J.C.B. Mohr.

Hegel, G.W.F. (1807) Phänomenologie des Geistes. Bamberg: Joseph Anton Goebhardt.

Higgs, B. (2014) 'Threshold concepts: Navigating the route'. In O'Mahony, C., Buchanan, A., O'Rourke M. and Higgs, B. (eds), Threshold Concepts: From personal practice to communities of practice. Proceedings of the National Academy's Sixth Annual Conference and the Fourth Biennial Threshold Concepts Conference. Cork: NAIRTL, 13-21.

Higgs, B. and Cronin, J.G.R. (2013) 'Threshold concepts: Informing the curriculum'. In O'Farrell, C. and Farrell, A. (eds), Emerging Issues in Higher Education III: From capacity building to sustainability. Athlone: Educational Developers in Ireland Network (EDIN), 161-77.

Hofer, B.K. (2001) 'Personal epistemology research: Implications for learning and teaching'. Journal of Educational Psychology Review, 13 (4), 353-83. https://doi.org/10.1023/A:1011965830686.

Hofer, B.K. and Pintrich, P.R. (1997) 'The development of epistemological theories: Beliefs about knowledge and knowing and their relation to learning'. Review of Educational Research, 67 (1), 88-140. https://doi.org/10.3102\%2F00346543067001088.

Jackson, F. (1998) From Metaphysics to Ethics: A defence of conceptual analysis. Oxford: Clarendon Press.

Kardash, C.M. and Scholes, R.J. (1996) 'Effects of preexisting beliefs, epistemological beliefs, and need for cognition on interpretation of controversial issues'. Journal of Educational Psychology, 88, 260-71. https://doi.org/10.1037/0022-0663.88.2.260.

Kohlmeier, J. (2006) '"Couldn't she just leave?": The relationship between consistently using class discussions and the development of historical empathy in a 9th grade world history course'. Theory \& Research in Social Education, 34 (1), 34-57. https://doi.org/10.1080/00933104.200 6.10473297.

Kuhn, T. (1962) The Structure of Scientific Revolutions. Chicago: University of Chicago Press.

Land, R. (2015) 'Facilitating the academy through threshold concepts and troublesome knowledge'. In Westergaard, E. and Wiewiura, J.S. (eds), On the Facilitation of the Academy. Rotterdam: Sense, 17-29.

Laurence, S. and Margolis, E. (2003) 'Concepts and conceptual analysis'. Philosophy and Phenomenological Research, 67 (2), 253-82. https://doi.org/10.1111/j.1933-1592.2003.tb00290.x.

Lee, P.J. (1998) '"A lot of guess work goes on": Children's understanding of historical accounts'. Teaching History, 92, 29-36.

Lee, P.J. (2004) 'Understanding history'. In Seixas, P. (ed.), Theorizing Historical Consciousness. New Toronto: University of Toronto Press. 
Lee, P.J. (2005) 'Historical literacy: Theory and research'. International Journal of Historical Learning, Teaching and Research, 5, 29-40.

Lee, P.J. and Ashby, R. (2000) 'Progression in historical understanding among students ages 7-14'. In Stearns, P., Seixas, P. and Wineburg, S. (eds), Knowing, Teaching and Learning History. New York: New York University Press, 199-223.

Lee, P.J. and Ashby, R. (2001) 'Empathy, perspective taking, and rational understanding'. In Davis Jr, O.L., Yaeger, E.A. and Foster, S.J. (eds), Historical Empathy and Perspective Taking in the Social Studies. Lanham, MD: Rowman \& Littlefield, 21-50.

Lee, P.J. and Shemilt, D. (2004) '"I just wish we could go back in the past and find out what really happened": Progression in understanding about historical accounts'. Teaching History, 117, 25-31.

Lévesque, S. (2005) 'Teaching second-order concepts in Canadian history: The importance of "historical significance"'. Canadian Social Studies, 39 (2). https://eric.ed.gov/?id=EJ1073987.

Lévesque, S. (2011) 'What it means to think historically'. In Clark, P. (ed.), New Possibilities for the Past: Shaping history education in Canada. Vancouver: UBC Press, 115-38.

Lodewyk, K.R. (2007) 'Relations among epistemological beliefs, academic achievement, and task performance in secondary school students'. Educational Psychology: An International Journal of Experimental Educational Psychology, 27 (3), 307-27. https://doi.org/10.1080/01443410601104080

Lowenthal, D. (2015) The Past is a Foreign Country - Revisited. Cambridge: Cambridge University Press.

Marton, F., Hounsell, D. and Entwistle, N. (eds) (2005) The Experience of Learning: Implications for teaching and studying in higher education. 3rd (internet) ed. Edinburgh: University of Edinburgh, Centre for Teaching, Learning and Assessment. www.ed.ac.uk/institute-academic-development/ learning-teaching/research/experience-of-learning (accessed 30 December 2020).

Massimi, M. (2018a) 'Four kinds of perspectival truth'. Philosophy and Phenomenological Research, 96 (2), 342-59. https://doi.org/10.1111/phpr.12300.

Massimi, M. (2018b) 'Perspectivism'. In Saatsi, J. (ed.), The Routledge Handbook of Scientific Realism. Abingdon: Routledge, 164-75.

Massimi, M. and McCoy, C.D. (eds) (2020) Understanding Perspectivism. Scientific challenges and methodological prospects. New York: Routledge.

McAleavy, T. (1998) 'The use of sources in school history 1910-1998: A critical perspective'. Teaching History, 91, 10-16.

McKeon, R. (1972) 'History and philosophy, art and science, validity and truth'. In Gadamer, H.-G. (ed.), Truth and Historicity. The Hague: Martinus Nijhoff, 42-8.

Meyer, J.H.F. and Land, R. (2003) Threshold Concepts and Troublesome Knowledge: Linkages to ways of thinking and practising within the disciplines. Edinburgh: ETL Project, Universities of Edinburgh, Coventry and Durham.

Meyer, J.H.F. and Land, R. (2005) 'Threshold concepts and troublesome knowledge (2): Epistemological considerations and a conceptual framework for teaching and learning'. Higher Education, 49, 373-88. https://doi.org/10.1007/s10734-004-6779-5.

Meyer, J.H.F. and Land, R. (2006) 'Threshold concepts and troublesome knowledge. An introduction'. In Meyer, J.H.F. and Land, R. (eds), Overcoming Barriers to Student Understanding: Threshold concepts and troublesome knowledge. Abingdon: Routledge, 3-18.

Middendorf, J. and Pace, D. (2004) 'Decoding the disciplines: A model for helping students learn disciplinary ways of thinking'. New Directions for Teaching and Learning, 98, 1-12. https://doi.org/10.1002/tl.142.

Muis, K.R., Pekrun, R., Sinatra, G.M., Azevedo, R., Trevors, G., Meier, E. and Heddy, B.C. (2015) 'The curious case of climate change: Testing a theoretical model of epistemic beliefs, epistemic emotions, and complex learning'. Learning and Instruction, 39, 168-83. https://doi.org/10.1016/j.learninstruc.2015.06.003.

Nietzsche, F. (1968) The Will to Power. Originally Der Wille zur Macht, 1901. New York: Vintage.

Nietzsche, F. (1989) On the Genealogy of Morals and Ecce Homo. New York: Vintage.

Pace, D. (2017) The Decoding the Disciplines Paradigm: Seven steps to increased student learning. Bloomington: Indiana University Press.

Perkins, D. (1998) 'The teaching for understanding framework'. In Blythe, T. and Associates (eds), The Teaching for Understanding Guide. San Francisco: Jossey-Bass, 17-24.

Perkins, D.N. (2009) Making Learning Whole: How seven principles of teaching can transform education. San Francisco: Jossey-Bass.

Perry, W.G. (1970) Forms of Intellectual and Ethical Development in the College Years. New York: Holt, Rinehart and Winston.

Pickles, E. (2010) 'How can students' use of historical evidence be enhanced? A research study of the role of knowledge in Year 8 to Year 13 students' interpretations of historical sources'. Teaching History, 139, 41-51. 
Ranke, L.v. (2011) 'Preface to the First Edition of Histories of the Latin and Germanic Peoples'. In Iggers, G.G. (ed.), The Theory and Practice of History: Leopold von Ranke, edited with an introduction by Georg G. Iggers. London: Routledge, 85-7.

Rorty, R. (1989) Contingency, Irony, and Solidarity. Cambridge: Cambridge University Press.

Rorty, R. (2003) 'Anti-clericalism and atheism'. In Wrathall, M.A. (ed.), Religion after Metaphysics. Cambridge: Cambridge University Press, 37-46.

Rukavina, I. and Daneman, M. (1996) 'Integration and its effect on acquiring knowledge about competing scientific theories from text'. Journal of Educational Psychology, 88 (2), 272-87. http://doi.org/10.1037/0022-0663.88.2.272.

Schommer, M. (1990) 'Effects of beliefs about the nature of knowledge on comprehension'. Journal of Educational Psychology, 82 (3), 498-504. http://doi.org/10.1037/0022-0663.82.3.498.

Schommer, M. (1994) 'An emerging conceptualization of epistemological beliefs and their role in learning'. In Garner, R. and Alexander, P.A. (eds), Beliefs About Text and Instruction with Text. Hillsdale, NJ: Lawrence Erlbaum Associates, 25-39.

Schommer-Aikins, M. (2004) 'Explaining the epistemological belief system: Introducing the embedded systemic model and coordinated research approach'. Educational Psychologist, 39 (1), 19-29. http://doi.org/10.1207/s15326985ep3901_3.

Schommer-Aikins, M. and Easter, M. (2006) 'Ways of knowing and epistemological beliefs: Combined effect on academic performance'. Educational Psychology, 26 (3), 411-23. http://doi.org/10.1080/01443410500341304.

Schommer-Aikins, M. and Hutter, R. (2002) 'Epistemological beliefs and thinking about everyday controversial issues'. The Journal of Psychology, 136 (1), 5-20. https://doi. org/10.1080/00223980209604134.

Schreiber, J.B. and Shinn, D. (2003) 'Epistemological beliefs of community college students and their learning processes'. Community College Journal of Research and Practice, 27 (8), 699-709. https://doi.org/10.1080/713838244.

Seixas, P. and Morton, T. (2013) The Big Six Historical Thinking Concepts. Toronto: Nelson Education.

Shemilt, D. (2000) 'The caliph's coin: The currency of narrative frameworks in history teaching'. In Seixas, P. Stearns, P. and Wineburg, S. (eds), Knowing, Teaching and Learning History. New York: New York University Press, 83-101.

Shinners-Kennedy, D. (2016) 'How not to identify threshold concepts'. In Land, R., Meyer, J.H.F. and Flanagan, M.T. (eds), Threshold Concepts in Practice. Rotterdam: Sense, 253-68.

Strømsø, H. and Ivar, B. (2009) 'Beliefs about knowledge and knowing and multiple-text comprehension among upper secondary students'. Educational Psychology, 29 (4), 425-45. https://doi.org/10.1080/01443410903046864.

Southgate, B.C. (2001) History, What and Why? Ancient, modern, and postmodern perspectives. 2nd ed. London: Routledge.

Tolhurts, D. (2007) 'The influence of learning environments on students' epistemological beliefs and learning outcomes'. Teaching in Higher Education, 12 (2), 219-33. https://doi. org/10.1080/13562510701191992.

Trevors, G.J., Muis, K.R., Pekrun, R., Sinatra, G.M. and Muijselaar, M.M.L. (2017) 'Exploring the relations between epistemic beliefs, emotions, and learning from texts'. Contemporary Educational Psychology, 48, 116-32. https://doi.org/10.1016/j.cedpsych.2016.10.001.

Turner, D.D. (2004) 'The past vs. the tiny: Historical science and the abductive arguments for realism'. Studies in History and Philosophy of Science, 35 (1), 1-17. https://doi.org/10.1016/j.shpsa.2003.12.012.

Van Fraassen, B. (1980) The Scientific Image. Oxford: Oxford University Press.

VanSledright, B. (2002) In Search of America's Past: Learning to read history in elementary school. New York: Teachers College Press.

Westphal, K.R. (2000) 'Hegel's internal critique of naïve realism'. Journal of Philosophical Research, 25, 173-229. https://doi.org/10.5840/jpr_2000_22.

Wineburg, S. (2001) Historical Thinking and Other Unnatural Acts: Charting the future of teaching the past. Philadelphia: Temple University Press. 